IZA DP No. 8730

The Production and Stock of College Graduates for U.S. States

John V. Winters

December 2014 


\title{
The Production and Stock of College Graduates for U.S. States
}

\author{
John V. Winters \\ Oklahoma State University \\ and IZA
}

\section{Discussion Paper No. 8730 \\ December 2014}

\author{
IZA \\ P.O. Box 7240 \\ 53072 Bonn \\ Germany \\ Phone: +49-228-3894-0 \\ Fax: +49-228-3894-180 \\ E-mail: iza@iza.org
}

Any opinions expressed here are those of the author(s) and not those of IZA. Research published in this series may include views on policy, but the institute itself takes no institutional policy positions. The IZA research network is committed to the IZA Guiding Principles of Research Integrity.

The Institute for the Study of Labor (IZA) in Bonn is a local and virtual international research center and a place of communication between science, politics and business. IZA is an independent nonprofit organization supported by Deutsche Post Foundation. The center is associated with the University of Bonn and offers a stimulating research environment through its international network, workshops and conferences, data service, project support, research visits and doctoral program. IZA engages in (i) original and internationally competitive research in all fields of labor economics, (ii) development of policy concepts, and (iii) dissemination of research results and concepts to the interested public.

IZA Discussion Papers often represent preliminary work and are circulated to encourage discussion. Citation of such a paper should account for its provisional character. A revised version may be available directly from the author. 
IZA Discussion Paper No. 8730

December 2014

\section{ABSTRACT}

\section{The Production and Stock of College Graduates for U.S. States*}

The stock of human capital in an area is important for regional economic growth and development. However, highly educated workers are often quite mobile and there is a concern that public investments in college graduates may not benefit the state if the college graduates leave the state after finishing their education. This paper examines the relationship between the production of college graduates from a state and the stock of college graduates residing in the state using microdata from the decennial census and American Community Survey. I examine the relationship across states and across cohorts within states. The descriptive analysis suggests that the relationship between the production and stock of college graduates has increased over time and is nearly proportional in recent years. I also employ instrumental variables methods to estimate causal effects. The preferred IV results yield an average point estimate for the production-stock relationship of 0.52 , but the effect likely decreases with age.

JEL Classification: $\quad$ I25, J24, R23

Keywords: college graduates, human capital, migration, higher education policy

Corresponding author:

John V. Winters

Oklahoma State University

331 Business Building

Stillwater, OK 74078-4011

USA

E-mail: jvwinte@okstate.edu

\footnotetext{
* The author gratefully acknowledges financial support from the W.E. Upjohn Institute for Employment Research Early Career Research Grant Program. Any errors or omissions are solely the responsibility of the author.
} 


\section{Introduction}

Previous researchers have shown that the local stock of human capital is important for regional economic growth and development. Highly educated workers have higher earnings and pay higher taxes, and their presence also benefits less educated workers in the local labor market. Educated workers create more and better jobs, increasing the earnings and employment rates of their less educated neighbors (Rauch 1993; Moretti 2004; Glaeser and Resseger 2010; Abel, Dey and Gabe 2012; Winters 2013). Educated workers are also thought to make areas more desirable places to live and increase the local quality of life (Shapiro 2006; Winters 2011a) and lead to future population growth (Simon 1998; Simon and Nardinelli 2002; Glaeser and Saiz 2004).

Because of the societal benefits of human capital, researchers and policymakers are interested in how states can grow their stock of highly educated workers. Striving to increase college graduation rates among the state's young people is one approach. However, college graduates are especially mobile and often leave their home state after graduation and therefore take the benefits of their human capital with them. State investments in graduates who leave the state may not provide sufficient benefits to the state to justify the costs.

The current paper investigates the relationship between the production and stock of college graduates for states in the U.S. I use microdata from the decennial census and American Community Survey (ACS) to measure both the production and stock of college graduates across and within states. The data report both the state in which an individual currently resides and the state in which they were born. Similarly to Bound et al. (2004), I measure the stock of college graduates in a state at a given point in time by the percentage of the state's residents of a given age at the time of the survey whose highest education is a bachelor's degree or higher. However, unlike Bound et al. (2004) I measure the production of college graduates by the percentage of 
persons of a given age born in a state who have earned at least a bachelor's degree by the time of the survey. I then regress the stock of college graduates in a state on the production from the state. I first look at cross-sectional differences across states and then look at differences across cohorts within states using state fixed effects.

Examining the production-stock relationship by measuring the production of college graduates based on individuals' birth states provides new insights to the literature on state human capital creation. Obviously, not everyone born in a state who earns a college degree does so in their native state and many young people leave their birth state even before entering college. However, the majority of young people continue to reside in their birth state. For example, in the 2012 ACS 71.8 percent of college enrollees ages 18-22 resided in their state of birth at the time of the survey. Furthermore, 81 percent of persons age 17 in the 2012 ACS resided in their birth state. Thus, measuring the production of college graduates among persons born in a state can provide useful insights, but care must be taken in interpreting the results.

An important concern is that both the production and stock of college graduates may be driven by economic conditions in the state that increase the demand for college-educated labor. If so, OLS regression coefficients will be biased and inconsistent. I account for this concern in two ways. First, I include a set of time-varying state controls measured at the time an individual is age 18; these include the wage premium for college graduates relative to high school graduates, the unemployment rate, median household income, cohort size, and a state merit aid program variable. Second, I use instrumental variables to obtain exogenous variation in the percentage of persons from the state who graduate from college. My preferred instrument uses lagged decennial census data to compute the average education levels of mothers of children of a given birth cohort. I then match the birth cohort maternal education levels to respondents of 
future ACS surveys. Thus, past increases in maternal education are used to predict future increases in the education levels of young adults.

Previewing the results, I consistently find a significantly positive relationship between the production of college graduates from a state and the stock of college graduates in the state. The descriptive analysis suggests that the cross-sectional bivariate relationship has increased over time and is nearly proportional in recent years, especially for younger persons. The preferred IV results yield an average point estimate for the production-stock relationship of 0.52 , though the effect likely decreases with age. These results have important implications for states and provide insights into how human capital affects regional economies. States can benefit from public investments that increase college completion rates among state natives. While some graduates will leave the state after completing their education, many will stay and help build the stock of college graduates in the state.

\section{Previous Literature}

Bound et al. (2004) examine how increased production of college graduates in a state affects the later stock of college graduates residing in the state years later. They compute bachelor's degree production rates from the Integrated Postsecondary Education Data System (IPEDS) and matched them to college educated stock rates in the 1960-1990 decennial censuses. ${ }^{1}$ Their baseline specification for 1990 suggests that a one percentage point increase in the production of college graduates in a state only increases the stock of college graduates in the state by about 0.3 percentage points. This modest coefficient suggests that the majority of the

\footnotetext{
${ }^{1}$ One limitation with the IPEDS data is that it does not report the age of graduates which can create some measurement error when assigning graduates from graduation years to cohort years. Bound et al. (2004) conduct a measurement error simulation exercise and conclude that measurement error likely only minimally affects their results.
} 
benefits from educating more graduates accrue to other states because the additional graduates are very likely to leave the state in which they were educated.

Two additional studies also use the IPEDS to examine the production-stock relationship for college graduates. Trostel (2010) combines IPEDS data with the 1992-2005 Current Population Survey (CPS) and finds the production-stock relationship to be nearly proportional. Abel and Deitz (2012) use the IPEDS with 2000 Census and 2006 ACS data to examine the production-stock relationship for college graduates within metropolitan areas. They find a small positive relationship. However, many metropolitan areas are too small and specialized to absorb even most of the human capital that they create, and this is especially true for relatively small college town metropolitan areas. Thus, the production-stock relationship for metro areas likely differs from that for states, which are typically larger.

More generally, a sizable literature has explored the various determinants and consequences of the migration decisions of both college graduates and non-graduates for the U.S. (Ferguson et al. 2007; Chen and Rosenthal 2008; Whisler et al. 2008; Partridge 2010; Partridge et al. 2010; Scott 2010; Hawley and Rork 2013; Faggian and Franklin 2014; McHenry 2014; Leguizamon and Hammond 2015; Zheng 2015) and other countries (Faggian, McCann, and Sheppard 2007a, 2007b; Hansen and Niedomys1 2009; Corcoran, Faggian, and McCann 2010; Brown and Scott 2012; Haapanen and Tervo 2012; Di Cintio and Grassi 2013; Faggian, Corcoran, and McCann 2013; Marinelli 2013; Venhorst 2013; Liu and Shen 2014; Miguélez and Moreno 2014; Carree and Kronenberg 2014; Abreu, Faggian, and McCann 2015). These studies collectively find that both amenities and employment opportunities have important effects on location decisions. 
Additionally, higher education appears to increase one's likelihood of moving away from their native state during adulthood (Malamud and Wozniak 2012). Machin, Salvanes and Pelkonen (2012) also find evidence that changes in compulsory schooling laws in Norway increased secondary education and as a result also increased internal migration rates. McHenry (2013), however, finds that increases in secondary education due to compulsory schooling laws in the U.S. actually reduce out-migration. There are, of course, considerable differences between the U.S. and Norway and between secondary and higher education and the conflicting results are not very surprising.

\section{Conceptual Framework}

States may be able to increase their stock of college graduates by increasing public investments in education. Increased state investment could take the form of greater public higher education subsidies used to decrease tuition rates and/or increase financial aid at the state's public colleges and universities. According to the law of demand, a reduction in the net price students pay should increase their participation in higher education (Leslie and Brinkman 1987). Other investments in higher education could involve creating new colleges and universities to increase access in areas that are long distances from affordable higher education institutions. Or higher education investments could be targeted to providing student support services, tutoring programs, smaller class sizes, and increased course availability (Bound, Lovenheim and Turner 2010). Alternatively, some observers suggest that inadequate college preparation may be an especially important barrier to college completion for more many students. This suggests that increased investments in primary and secondary education may be an effective way for many states to increase college completion rates among their young people. 
There is, however, a concern that increasing the production of college graduates will not translate into an increase in the stock of college graduates because of out-migration. If there were no migration, a one percentage point increase in college graduate production would lead to a one percentage point increase in the college graduate stock. However, because migration is possible, the relationship is likely not proportional. In fact, if there were perfect geographic mobility such that later life location decisions were independent of earlier ones, the correlation between the production and stock of graduates would be zero. In reality, there are moving costs and individuals are not perfectly mobile across areas. Many individuals have attachments to family, friends, and other local attributes that make them reluctant to move. ${ }^{2}$ The relationship between the production and stock of college graduates is ultimately an empirical question.

The current paper measures the production of college graduates from a state by the percentage of persons of a given age cohort born in a state who have earned at least a bachelor's degree by the time of the survey. This approach provides new insights, albeit to a different question than that addressed by previous researchers measuring college graduate production using IPEDS data. IPEDS data measure the production of college graduates in a state. I examine the effects of increasing the production of college graduates among persons from a state independent of where they complete their degree.

The production of college graduates in state $j$ using IPEDS data includes both persons from state $j$ and persons originally from states (or nations) other than $j$ who earn a bachelor's degree at a college or university in state $j$. Increasing the production of college graduates in state $j$ can be achieved in multiple ways. First, policymakers can encourage more non-residents to

\footnotetext{
${ }^{2}$ Winters (2011b) suggests that the relationship between metropolitan human capital levels and future population growth is largely driven by students moving to an area for college and then staying in the area after finishing their education. He postulates that some students stay because of attachments they make while in college.
} 
attend and complete college in state $j$; call this mechanism 1. Most of these additional nonresident graduates likely would have otherwise attended and completed college in another state but it could also include some people who would not have completed college had they not done so in state $j$. Second, policymakers can encourage more residents of state $j$ to attend and complete college in state $j$, which can be achieved via two possible mechanisms that affect young people making decisions at different margins. Some residents of state $j$ are very likely to complete a college degree somewhere, but they are making marginal location decisions about where to earn their degree. Policymakers may be able to encourage these residents from $j$ to stay in-state for college and earn their degree in their home state $j$; call this mechanism 2. Finally, there are young people from state $j$ who are at the margin of whether or not to attend and complete college at all; their location decisions may be viewed as infra-marginal. Policymakers may be able to encourage these young people to complete college and do so in state $j$; call this mechanism 3. Therefore, the IPEDS college graduate production measure is affected by both changes in college location decisions and changes in college completion independent of location decisions.

My measure of the production of college graduates among persons from state $j$ does not depend on where they earn their degree. Therefore, effects from mechanisms 1 and 2 are not captured by measure. My measure is partially related to mechanism 3 but not perfectly. Policymakers may be able to encourage young people from state $j$ at the margin of whether or not to attend and complete college at all to attend and complete college in state $j$ and that would be included in my measure and in the IPEDS measure via mechanism 3. However, my measure also includes effects due to policy changes that encourage young people from state $j$ at the 
margin of whether or not to attend and complete college at all to attend and complete college in a state other than $j$.

For example, tuition and financial aid policies in state $j$ for state residents might encourage young people from state $j$ along both the location and completion margins consistent with mechanisms 2 and 3. In other words, lowering the net costs of college for residents in state $j$ would likely encourage state $j$ residents making marginal location decisions to attend college in-state and likely affect state $j$ residents making marginal educational decisions to complete college in-state. Alternatively, suppose that policymakers make additional investments that improve K-12 education in state $j$. This will increase college preparation for young persons from state $j$ and increase their likelihood of completing college but have an unclear effect on where they complete college.

My college graduate production measure captures increased production regardless of where young people actually earn their degree. This measure is not directly linked to any specific higher education policy. Instead, it is most closely related with the broad policy goal of increasing college attainment among the state's young people. To my knowledge, this is the first study to examine the production-stock relationship for college graduates in this way and therefore offers new insights to an important field of research.

\section{Data and Empirical Approach}

The data for this paper come primarily from the decennial census and the American Community Survey (ACS) and were accessed from IPUMS (Ruggles et al 2010). I first examine the cross-sectional bivariate relationship between the production and stock of college graduates 
across states using the decennial census for 1960-2000 and using the ACS for 2006 and 2012.

More specifically, I estimate several Ordinary Least Squares (OLS) regressions of the form:

$$
\text { Stock }_{\text {sta }}=\alpha+\beta_{\text {ta }} \text { Production }_{\text {sta }}+\varepsilon_{\text {sta }}
$$

I measure the stock of college graduates in state $s$ in year $t$ for age group $a$ by the percentage of state residents of that age at the time of the survey who have completed at least a bachelor's degree. I measure the production of college graduates in state $s$ by year $t$ for age group $a$ by the percentage of persons in that age group born in the state who have earned at least a bachelor's degree by the time of the survey. Prior to the 1990 census, education categories were reported based on the number of years of schooling and do not explicitly report college degrees earned. For 1960-1980, I consider someone to be a college graduate if they had completed at least four years of college. Beginning in 1990, the education variable reports the highest degree completed, and I can directly identify persons who have completed at least a bachelor's degree. I restrict the initial sample to persons ages 25-59. I examine the production-stock relationship for the full 25-59 age-range and separately for five-year age groups. ${ }^{3}$ The $\beta$ coefficient is also allowed to vary over time.

The bivariate cross-sectional relationship between the production and stock of college graduates across states is intended to be descriptive and not necessarily causal. Both the production and stock of college graduates may be driven by economic conditions in the state that increase the demand for college-educated labor. If so, OLS regression coefficients of equation (1) will not represent a causal relationship. I next modify the cross-sectional analysis by pooling the 2006-2012 ACS and estimating:

Stock $_{\text {stac }}=\alpha+\beta$ Production $_{\text {stac }}+\gamma$ StateControls $_{\text {stac }}+\delta_{s}+\theta_{t}+\pi_{a}+\varphi_{c}+\varepsilon_{\text {stac }}(2)$

\footnotetext{
${ }^{3}$ Regression results reported in this paper are estimated using state-year-age cohort sizes as weights. Unweighted regressions are qualitatively similar.
} 
, where $s, t$, and $a$ again index state, survey year, and age at the time of the survey, and $c$ now indexes year-of-birth cohort, where year-of-birth is computed as the survey year minus age at the time of the survey. State fixed effects $\left(\delta_{s}\right)$ control for persistent differences across states in human capital levels. Identification then comes from differences across cohorts within states. I also include dummy variables for survey year $\left(\theta_{t}\right)$, age $\left(\pi_{a}\right)$, and year of birth $\left(\varphi_{c}\right)$; since these last three are somewhat redundant, perfectly collinear variables are dropped. The regression also includes a set of cohort-varying state controls, which are discussed further below.

Estimating equation (2) could still produce biased and inconsistent estimates of $\beta$ for two main reasons. First, there may still be unobserved cohort-specific factors within states that are correlated with both the production and stock of college graduates. Second, the production of college graduates is likely measured with some degree of error due to sampling. Each year of the 2006-12 ACS includes a one percent sample of the population. States are sufficiently large that these samples will typically produce fairly precise estimates of the true population characteristics, but problems with measurement error are greatly exacerbated when variables are measured by single year of age and controlling for state fixed effects and the other variables. Classical measurement error will attenuate coefficients toward zero.

I next use an instrumental variables (IV) strategy that is intended to account for both potential sources of bias discussed above. More specifically, I use the 1980 and 1990 decennial census microdata to compute maternal education levels for children by state and birth cohort. I then match the birth cohort maternal education levels to young adults in the 2006-12 ACS based on state-of-birth and year-of-birth. Thus, past increases in maternal education are used to predict future increases in education levels for the next generation. The motivation for the instrument used comes from the literature on the intergenerational transmission of education (Behrman and 
Rosenzweig 2002; Black, Devereux and Salvanes 2005; Björklund and Salvanes 2011; Chevalier et al. 2013). This literature generally finds that maternal education is strongly positively correlated with later child education outcomes. ${ }^{4}$ Maternal education has been used as an instrument for education at the individual level (see Card 1999 and Hoogerheide, Block and Thurik 2012), but I am unaware of any other researchers using cohort-level maternal education as an instrument for cohort-level education levels. ${ }^{5}$

There are some issues with the maternal education IV strategy. First, the questionnaire does not directly ask survey participants to report their mother's education. Instead, it can be computed indirectly for persons living in the same house as their mother based on the mother's reported education. This means we cannot observe maternal education for most adults, but we can for most children. Most persons graduate high school around age 18 and then often move out of their parents' house to go to college or establish their own residences, and persons who reside with their parents after age 18 are likely to differ in their eventual education levels from persons who have already left. Thus, one cannot use census data to credibly compute maternal education levels for adults. Instead, I compute maternal education levels for children age 17 or younger at the time of the 1980 and 1990 census surveys (based on April 1 of the census year).

Additionally, some children live separately from their mother, and many children live separately from their biological mother and with an adopted mother or stepmother. In such cases it is unclear how adoptive mothers and stepmothers should be treated. To construct my instrument, I treat all "mothers" living with their children the same, i.e., I do not differentiate between biological mothers, stepmothers, and adoptive mothers who live in the same residence

\footnotetext{
${ }^{4}$ One could also consider using an instrument based on paternal education, but a much higher percentage of children have no father figure present in the household, so paternal education is likely a less reliable instrument.

${ }^{5}$ Winters (2015) uses cohort-level maternal education as an instrument to estimate the wage returns to years of schooling.
} 
as their child. However, I must exclude all children who live with no mother, stepmother or adoptive mother in computing the instrument. These issues will introduce some measurement error in the instrument, but I assume the measurement error is random measurement error at the state-cohort level and fairly minimal. The two stage least squares (2SLS) procedure used can account for random measurement error in the instrument so long as the measurement error is not severe. Fortunately, 93 percent of children ages 0-17 live with a "mother" so cohort-level maternal education levels should be reasonably accurately estimated. ${ }^{6}$ For those with maternal education reported, I compute the percentage of the state-of-birth and year-of-birth cohort whose mother had completed a bachelor's degree or higher and use this as my instrument. One could also consider computing mean maternal years of schooling, but since I am instrumenting for the production of college graduates, maternal education levels should likely be focused on college graduates also.

The 2SLS regression analysis below matches maternal education levels from the 1980 and 1990 census 5\% PUMS to adults ages 25-49 in the 2006-2012 ACS who were born between 1963 and 1987. ${ }^{1}$ I exclude earlier years of the ACS because they do not include the group quarters population, though including them does not substantially alter the results. Persons older than age 49 in 2006-2012 were born before 1963. Persons born before 1963 were older than 17

\footnotetext{
${ }^{6}$ One could also consider excluding children who live with a stepmother or adoptive mother, but this could meaningfully alter the composition of children included in the measure and weaken both the power and validity of the instrument. Furthermore, even if one thinks that biological mothers are the most relevant group of mothers, they are not observed for many children and arguably the best available way to impute their biological mother's education is based on their non-biological mother's education. Finally, I am using a cohort level measure of maternal education, so individual "mis-measurement" in maternal education from stepmothers and adoptive mothers is likely to average out to some extent if biological mothers and co-residential stepmothers and adoptive mothers have similar education levels.

${ }^{7}$ A few cohorts were under age 18 in both 1980 and 1990, i.e., those born 1973-1980. I assign maternal education levels for these cohorts based on the 1990 census, in part because the education measure was better in 1990 than in 1980 as noted above. Thus, the 1963-1972 birth cohorts have maternal education from the 1980 census, and the 1973-1987 cohorts have maternal education from the 1990 census. Using the 1980 census maternal education instead for the overlapping years produces nearly identical results.
} 
in 1980, and lack reliable maternal education levels. ${ }^{8}$ Persons born after 1987 had not reached age 25 by 2012 .

A valid instrument should be both relevant and exogenous. The relevance assumption requires that the instrument have a strong statistically significant effect on the potentially endogenous explanatory variable in the first stage of a 2 SLS regression. The exogeneity assumption requires that the instrument be uncorrelated with the error term in the second stage equation, that is, the instrument should only be correlated with the dependent variable through its effect on the potentially endogenous variable for which it is being used as an instrument. One can test the relevance assumption and I provide evidence on this below, but one cannot test the exogeneity assumption for only one instrument. Conceptually, however, cohort-level maternal education seems a plausible instrument in this setting. First, computing the instrument using the 1980 and 1990 censuses and first observing the dependent variable at least 16 years later reduces concerns that maternal education might somehow be affected by contemporaneous labor market conditions that also increase the education level of state residents. More importantly, including state and year-of-birth fixed effects controls for unobserved state effects and unobserved time effects. Identification comes from variation in maternal education across cohorts within states. This variation is likely due to largely random factors such as state higher education policies and changing expectations about female education, labor force participation, and fertility that affected states differently at different times.

Equation (2) also includes a set of cohort-varying state control variables. I control for the cohort sex, race, and ethnicity distributions by including separate variables for the percentage of

\footnotetext{
${ }^{8}$ I considered using the 1970 Census to estimate maternal education levels for older cohorts, but I decided against it in order to focus on persons in age ranges with stronger attachments to the labor force. Maternal college graduation rates were also much lower in 1970 and the available samples are only $1 \%$ instead of $5 \%$ of the population, so using 1970 maternal education would likely weaken the instrument.
} 
cohort $c$ born in state $s$ observed in survey year $t$ who are female, black, Asian, Hispanic, and other non-white. I also include additional cohort-varying state of birth control variables measured at the time an individual is age 18; these include the college wage premium, the unemployment rate, the log of median household income, the log of the cohort size, and a dummy for whether the state of birth had adopted a state merit scholarship plan by the time the cohort was age $18 .^{9}$ The college wage premium and log median household income are computed from the March Current Population Survey (CPS). The college wage premium is measured as the log wage premium in the state between persons with only a high school diploma and persons with only a bachelor's degree for full-time (35+ hours per week) and full-year (35+ weeks per year) workers ages 25-54. The unemployment rate is obtained from the Bureau of Labor Statistics (BLS). Cohort size data are obtained from the Census Bureau's intercensal population estimates. The merit aid dummy variable is from Sjoquist and Winters $(2014,2015)$. They report that 27 states adopted some form of a state merit aid program between 1990 and 2005, though they primarily focus on nine states with especially large programs. Sjoquist and Winters $(2014,2015)$ find that these merit programs had no effect on an individual's educational attainment, but they did make them on average more likely to reside in their birth state postcollege. $^{10}$

\footnotetext{
${ }^{9}$ Results below are robust to also including controls for these state characteristics at age 22 .

${ }^{10}$ The dummy is equal to zero for all states not adopting merit aid. For merit adopting states, the dummy equals zero for cohorts age 18 before the program was implemented and one for cohorts age 18 after the merit program was implemented. I use a single dummy for all merit aid programs, but results below are qualitatively robust to using separate dummies for strong and weak merit states as defined in Sjoquist and Winters (2014, 2015).
} 


\section{Empirical Results}

\subsection{Bivariate Cross-Sectional Relationship between the Production and Stock}

Table 1 illustrates the bivariate cross-sectional relationship between the production and stock of college graduates across states in the 2012 ACS. It lists each of the 50 states, the college share for each state by birth and by residence, and the state's college share rank by birth and residence, with the most educated state ranked first and the least educated ranked $50^{\text {th }}$. The college shares report the percentage of persons ages 25-59 who have at least a bachelor's degree. The college share by state of birth ranges from a high of 41.0 percent in Connecticut to a low of 23.6 percent in West Virginia. The college share by state of residence ranges from a high of 42.9 percent in Massachusetts to a low of 20.0 percent in West Virginia. There are some moderate exceptions, but overall the two college share measures are quite similar for most states. Massachusetts and Connecticut are the top two in both measures and Mississippi and West Virginia are the bottom two in both measures. The correlation coefficient between the college share by state of birth and state of residence is 0.795 ; the Spearman rank correlation coefficient is 0.808 . Overall, states that produce a high percentage of college graduates tend to have a large stock of college graduates in residence.

Table 2 reports estimation results for equation (1) separately for ages 25-59 and for fiveyear age groups for the 1960-2000 decennial and the 2006 and 2012 ACS. The bivariate production-stock coefficient is statistically different from zero for all age groups in all years considered. In 1960, the coefficient for ages $25-59$ was only 0.493 , suggesting that a one percentage point increase in the college share among persons born in the state is associated with an increase in the college share among persons residing in the state by 0.49 percentage points. This positive coefficient is statistically different from one. The production-stock coefficient for 
ages 25-59 grows steadily over time and by 2012 the coefficient is 0.847 and is not statistically different from one at the five percent level of significance. Thus, by 2012 the cross-sectional relationship between the production and stock of college graduates ages 25-59 across states is such that a one percentage point increase in the share of college graduates from a state is associated with a nearly one percentage point increase in the share of college graduates residing in the state.

The coefficient estimates for five-year age groups also increase over time and by 2012, the coefficient estimates are not statistically different from one for ages $25-29$ and 30-34. The coefficients also generally decrease by age. For 2012 the production-stock coefficient for persons ages 55-59 is "only" 0.606, which is a good bit less than one. This likely results primarily because an individual's likelihood of living in their state of birth declines as they age. Each year some members of a cohort leave and while some move back, the net effect is an increasing outflow over time. This suggests that the relationship between the production and stock of college graduates should decline with age.

While the relationships characterized in Table 2 are descriptive, the fact that the production-stock coefficient has increased so substantially over time likely has important but not fully understood implications. First, one wonders whether this trend will continue into the future and if so by how much. Will the coefficients ever significantly exceed one? What is driving the increase? At least a couple of factors may have a plausible role in the increase over time. First, migration rates have declined significantly in recent years (Molloy, Smith, and Wozniak 2011; Partridge, Rickman, Olfert, and Ali 2012). As people become less mobile, the characteristics of a state's residents will begin to look more like the characteristics of the state's natives. This is true for education, but also for other characteristics. A second yet quite different explanation is 
that high human capital workers may be becoming increasingly complementary with other high human capital workers causing high human capital workers to cluster in specific areas and average human capital levels to diverge across space as suggested by Berry and Glaeser (2005), Moretti (2013), and Lindley and Machin (2014). The analysis here is unable to shed much light on how important these factors are for explaining the increased production-stock coefficient over time, but this increase is an important empirical finding in need of future research.

\subsection{OLS Effects across Cohorts within States}

Table 3 presents OLS results for equation (2) in which the variables are now measured by survey year and single year of age. Standard errors are clustered by state. The sample is the 2006-2012 ACS cohorts ages 25-49 who were born between 1963 and 1987. I use the same restrictions as when using the maternal education instrument to increase comparability of the results. The first column of Table 3 reports the regression coefficient with no controls. The second column adds age, survey year, and year-of-birth dummies. The third adds state fixed effects, and the fourth adds the time-varying state controls.

Columns 1 and 2 without the state fixed effects report similar coefficients of 0.827 and 0.815 , respectively, that are statistically different from both zero and one at the one percent level of significance. These coefficients are also quite comparable to the results in Table 2 for 2006 and 2012. Adding the state fixed effects, however, reduces the coefficient to 0.521 in column 3 . Adding the time-varying state controls further reduces the coefficient to 0.477 in the fourth column. The results seem to suggest that much of the cross-sectional relationship between the production and stock of college graduates is driven by time-invariant state-specific unobserved factors. However, the decrease could also be attributable to measurement error bias that is 
exacerbated by the state fixed effects. The IV approach below will account for measurement error and other sources of bias.

\subsection{SLS Estimates Using Maternal Education as an Instrument}

Table 4 presents results for equation (2) that instrument for the production of college graduates from a state for a given age cohort using the maternal education instrument. More specifically, the instrument is the percentage of a birth cohort whose mother has at least a bachelor's degree in the 1980 or 1990 census. The sample is the 2006-2012 ACS cohorts ages 25-49 who were born between 1963 and 1987. Table 4 follows the structure of Table 3, with four columns that add progressively more control variables. Standard errors are clustered by state. The upper panel of Table 4 presents the first stage results for the excluded instrument, and the lower panel reports the 2SLS results for the birth state college share production variable. For all four columns of Table 4, the first stage coefficients for the excluded instrument are highly significant and the F-Statistics are well above 10, which satisfies a rule of thumb suggested by Stock, Yogo and Wright (2002) and Angrist and Pischke (2009) to test for weak instruments. An F-statistic greater than 10 suggests that weak instrument bias is likely to be very minimal.

The second stage coefficients for the birth state college share in Table 4 are all positive and statistically different from zero at least at the five percent level. The coefficients for the first two columns are 1.033 and 1.107 , respectively, and neither is statistically significantly different from one. Adding state fixed effects reduces the coefficient to 0.870 in the third column, but it is still not significantly different from one. However, adding the time-varying state controls lowers the coefficient to 0.522 , and it is significantly less than one at the five percent level. The results 
confirm that controlling for state fixed effects and time-varying state characteristics are important, even when using instrumental variables.

The results in the fourth column of Table 4 are the preferred estimates. The significant coefficient of 0.522 confirms that increased production of college graduates from a state does have an economically meaningful effect on the stock of college graduates residing in the state. However, the effect is much less than proportional. The results suggest that increasing college graduation rates of a state's natives by one percentage point will increase the percentage of the state resident's with a college degree by 0.52 percentage points.

\subsection{Separate 2SLS Estimates for Ages 25-35 and 36-49}

The descriptive analysis in Table 2 suggests that the production-stock relationship might differ by age. I next divide the sample into two age groups, 25-35 and 36-49, and estimate separate 2SLS results for the two age groups. ${ }^{11}$ Other sample restrictions correspond to those in Table 4. Results are reported in Table 5 using maternal education as an instrument and include the full set of controls. The instrument is significant in the first-stage for both age groups with FStatistics exceeding 10.

The second stage coefficients are both positive and statistically significantly different from zero. However, the coefficient magnitude appears to vary between the two age groups. For persons ages $25-35$ in column 1 the production-stock coefficients is 0.75 and is not significantly different from one. However, for ages 35-49 in column 2 the production-stock coefficient is only 0.366 and is significantly different from one. This suggests that the relationship between the production and stock of college graduates decreases with age as suggested in Table 2 .

\footnotetext{
${ }^{11}$ Splitting the sample based on these ages divides the sample using the maternal education instrument exactly in half. Results are qualitatively robust to moderate changes in the age ranges considered.
} 
However, it is worth noting that Table 2 also suggests that there may be generational effects with younger generations being less mobile in general. Generational differences could explain the results in Table 5 as well.

\subsection{Additional Results}

As a robustness check I also implemented a second instrumental variable (IV) strategy primarily intended to account for bias due to measurement error. This alternative IV strategy instruments for the production of college graduates from state $s$ and cohort $c$ observed in survey year $t$ using the production of college graduates from state $s$ and cohort $c$ observed in survey year $t-1$. That is, I instrument for the college share from a state of birth for a given cohort by using the one survey year lag for that cohort. If the measurement error is solely due to sampling and independent across years, this IV approach will eliminate any bias from measurement error. However, it will not address concerns about bias from omitted variables correlated with both the production and stock.

Results for this procedure are presented in Appendix Table A, which follows the same structure as Tables 3 and $4 .^{12}$ The instrument is significant in the first-stage for all specifications with F-Statistics exceeding 10. The results with the full set of controls give a production-stock of coefficient of 0.638 , which is not statistically different from that obtained using the maternal education instrument. Appendix Table B reports results estimating equation (2) jointly using both instruments; the second-stage coefficient estimate with the full controls is 0.557 . Appendix

\footnotetext{
${ }^{12}$ The sample is now the 2007-2012 ACS cohorts ages 25-49 who were born between 1963 and 1987. The 2006 ACS observation are now dropped from the second stage because I choose not to use the 2005 ACS in the instrument since persons in group quarters are excluded in that year. From a practical standpoint, the results are qualitatively robust to including the 2006 cohorts and using the 2005 ACS for the instrument. To avoid losing further observations, I use the college share at age 24 in the instrument in order to include persons age 25 in the second stage.
} 
Table $\mathrm{C}$ presents additional results by age group using the one-year lag instrument and both instruments. However, the preferred results in this paper continue to be those that use only the maternal education instrument.

\section{Conclusion}

College graduates are very important to state economies, but they are also especially mobile and there is a concern that out-migration may significantly reduce a state's return on public investments in college graduates. This paper examines the relationship between the production of college graduates from a state and the stock of college graduates residing in the state years later using microdata from the decennial census and American Community Survey. I measure the production of college graduates from a state by the percentage of persons of a given age born in a state who have earned at least a bachelor's degree, and I measure the stock of college graduates in a state by the percentage of the state's residents of a given age with a bachelor's degree or higher.

Cross-sectional OLS estimates suggest that the bivariate relationship between the production and stock of college graduates has increased in recent years and is nearly proportional, especially for younger persons. My preferred estimates, however, utilize state fixed effects so that identification comes from across cohorts within states. I also address potential endogeneity by instrumenting for college graduate production using lagged maternal education levels. The preferred IV results yield a point estimate for the production-stock relationship of 0.52 . However, I also find that the production-stock relationship decreases with age. 
The results in this paper suggest that public investments that increase college graduation rates among young people from the state can offer considerable benefits to the state. While many college graduates will leave the state after finishing their education, many others will stay, at least for some time, and help build the stock of human capital in the state. However, an important question left unanswered by this paper is how states can best increase college graduation rates among young people from the state. Over the past two decades several states have adopted state merit-based financial aid programs attempting to boost higher education in their state. Unfortunately, these merit aid programs have not increased college completion rates (Sjoquist and Winters 2015; Fitzpatrick and Jones 2012). Need-based aid programs may have some potential to increase completion, but Federal Pell grants and student loans are already sufficiently generous that financial need may not be a major obstacle to college success.

Other obstacles to college success may be more pertinent. According to the 2012 ACS, more than two-thirds of young adults have attended at least some college by age 25 . However, less than half of those with some college have completed a bachelor's degree or higher, even by age 30. Clearly, getting people in the door is not the problem. The problem is that so many drop out without completing a degree, largely because of inadequate student preparation and decreases in institutional resources per student (Bound, Lovenheim and Turner 2010). Thus, states interested in growing their stock of college graduates may be well served by increasing public investments in primary, secondary, and higher education in the state that are targeted to helping students obtain a high quality education and succeed in college. 


\section{References}

Abel, Jaison R. and Richard Deitz. 2012. Do colleges and universities increase their region's human capital? Journal of Economic Geography, 12: 667-691.

Abel, Jaison R., Ishita Dey, and Todd M. Gabe. 2012. Productivity and the density of human capital. Journal of Regional Science, 52: 562-586.

Abreu Maria, Alessandra Faggian, and Philip McCann. 2015. Migration and Inter-industry mobility of UK graduates. Journal of Economic Geography, Forthcoming, doi: 10.1093/jeg/lbt043.

Angrist, Joshua D. and Jorn-Steffen Pischke. 2009. Mostly Harmless Econometrics. Princeton: Princeton University Press.

Behrman, Jere R. and Mark R. Rosenzweig. 2002. Does increasing women's schooling raise the schooling of the next generation? American Economic Review, 92(1): 323-334.

Berry, Christopher R., and Edward L. Glaeser. 2005. The divergence of human capital levels across cities. Papers in Regional Science, 84: 407-444.

Björklund Anders, and Kjell G. Salvanes. 2011. Education and family background: Mechanisms and policies. In: Hanushek, Eric, Stephen Machin and Ludger Woessmann (eds.), Handbook of the Economics of Education, Vol. 3, Elsevier, 201-247.

Black, Sandra E., Paul J. Devereux, Kjell G. Salvanes. 2005. Why the apple doesn't fall far: Understanding intergenerational transmission of human capital. American Economic Review, 95(1): 437-449.

Bound, John, Jeffrey Groen, Gabor Kezdi, and Sarah Turner. 2004. Trade in university training: Cross-state variation in the production and stock of college-educated labor. Journal of Econometrics, 121(1-2): 143-173. 
Bound, John, Michael F. Lovenheim, and Sarah Turner. 2010. Why have college completion rates declined? An analysis of changing student preparation and collegiate resources. American Economic Journal: Applied Economics, 2(3): 129-157.

Brown, W. Mark and Darren M. Scott. 2012. Human capital location choice: Accounting for amenities and thick labor markets. Journal of Regional Science, 52(5): 787-808.

Card, David. 1999. The causal effect of education on earnings. In: Ashenfelter, Orley and David Card (eds.), Handbook of Labor Economics, Vol. 3, Elsevier, 1801-1863.

Carree, Martin, and Kristin Kronenberg. 2014. Locational choices and the costs of distance: Empirical evidence for Dutch graduates. Spatial Economic Analysis, 9(4): 420-435.

Chen, Yong and Stuart S. Rosenthal. 2008. Local amenities and life-cycle migration: Do people move for jobs or fun? Journal of Urban Economics, 64: 519-537.

Chevalier, Arnaud, Colm Harmon, Vincent O'Sullivan, and Ian Walker. 2013. The impact of parental income and education on the schooling of their children. IZA Journal of Labor Economics, 2(8): 1-22.

Corcoran Jonathan, Alessandra Faggian, and Philip McCann. 2010. Human capital in remote and rural Australia: The role of graduate migration. Growth and Change, 41(2): 192-210.

Di Cintio, Marco and Emanuele Grassi. 2013. Internal migration and wages of Italian university graduates. Papers in Regional Science, 92(1): 119-140.

Faggian, Alessandra, Jonathan Corcoran, and Philip McCann. 2013. Modelling geographical graduate job search using circular statistics. Papers in Regional Science, 92(2): 329-343.

Faggian, Alessandra and Rachel S. Franklin. 2014. Human capital redistribution in the USA: The migration of the college-bound. Spatial Economic Analysis, 9(4): 376-395. 
Faggian, Alessandra, Philip McCann, and Stephen Sheppard. 2007a. Some evidence that women are more mobile than men: Gender differences in UK graduate migration behavior. Journal of Regional Science, 47(3): 517-539.

Faggian, Alessandra, Philip McCann, and Stephen Sheppard. 2007b. Human Capital, higher education and graduate migration: An analysis of Scottish and Welsh students. Urban Studies, 44(13): 2511-2528.

Ferguson, Mark, Kamar Ali, M. Rose Olfert, and Mark D. Partridge. 2007. Voting with their feet: Jobs versus amenities. Growth and Change, 38(1): 77-110.

Fitzpatrick, Maria and Damon Jones. 2012. Higher education, merit-based scholarships and postbaccalaureate migration. NBER Working Paper 18530.

Glaeser, Edward L. and Matthew G. Resseger. 2010. The complementarity between cities and skills. Journal of Regional Science, 50: 221-244.

Glaeser, Edward L., and Albert Saiz. 2004. The rise of the skilled city. Brookings-Wharton Papers on Urban Affairs, 47-94.

Haapanen, Mika and Hannu Tervo. 2012. Migration of the highly educated: Evidence from residence spells of university graduates. Journal of Regional Science, 52(4): 587-605.

Hansen, Høgni Kalsø and Thomas Niedomysl 2009. Migration of the creative class: Evidence from Sweden. Journal of Economic Geography, 9(2): 191-206.

Hawley, Zackary B. and Jonathan C. Rork 2013. The case of state funded higher education scholarship plans and interstate brain drain. Regional Science and Urban Economics, 43(2): 242-249. 
Hoogerheide, Lennart, Joern H. Block and Roy Thurik. 2012. Family background variables as instruments for education in income regressions: A Bayesian analysis. Economics of Education Review, 31(5): 515-523.

Leguizamon, J. Sebastian, and George W. Hammond. 2015. Merit-based college tuition assistance and the conditional probability of in-state work. Papers in Regional Science, Forthcoming.

Leslie, Larry L. and Paul T. Brinkman. 1987. Student price response in higher education: The student demand studies. Journal of Higher Education, 58(2): 181-204.

Lindley, Joanne, and Stephen Machin. 2014. Spatial changes in labour market inequality. Journal of Urban Economics, 79: 121-138.

Liu, Ye, and Jianfa Shen. 2014. Spatial patterns and determinants of skilled internal migration in China, 2000-2005. Papers in Regional Science, 93(4): 749-771.

Machin, Stephen, Kjell G. Salvanes and Panu Pelkonen. 2012. Education and mobility. Journal of the European Economic Association, 10(2): 417-450.

Malamud, Ofer, and Abigail K. Wozniak. 2012. The impact of college on migration: Evidence from the Vietnam generation. Journal of Human Resources, 47(4): 913-950.

Marinelli, Elisabetta. 2013. Sub-national graduate mobility and knowledge flows: An exploratory analysis of onward-and return-migrants in Italy. Regional Studies 47(10): 1618-1633.

McHenry, Peter. 2013. The relationship between schooling and migration: Evidence from compulsory schooling laws. Economics of Education Review, 35: 24-40.

McHenry, Peter. 2014. The geographic distribution of human capital: Measurement of contributing mechanisms. Journal of Region Science, 54(2): 215-248. 
Miguélez, Ernest, and Rosina Moreno. 2014. What attracts knowledge workers? The role of space and social networks. Journal of Regional Science, 54(1): 33-60.

Molloy, Raven, Christopher L. Smith, and Abigail Wozniak. 2011. Internal migration in the United States. Journal of Economic Perspectives, 25(3): 173-96.

Moretti, Enrico. 2004. Estimating the social return to higher education: Evidence from longitudinal and repeated cross-sectional data. Journal of Econometrics, 121: 175-212.

Moretti, Enrico. 2013. The New Geography of Jobs. New York: Houghton Mifflin Harcourt.

Partridge, Mark D. 2010. The dueling models: NEG vs amenity migration in explaining US engines of growth. Papers in Regional Science, 89(3): 513-536.

Partridge, Mark D., Dan S. Rickman, Kamar Ali and M. Rose Olfert. 2010. Recent spatial growth dynamics in wages and housing costs: Proximity to urban production externalities and consumer amenities. Regional Science and Urban Economics, 40(6): 440-452.

Partridge, Mark D., Dan S. Rickman, M. Rose Olfert, and Kamar Ali. 2012. Dwindling U.S. internal migration: Evidence of spatial equilibrium or structural shifts in local labor markets? Regional Science and Urban Economics, 42: 375-388.

Rauch, James E. 1993. Productivity gains from geographic concentration of human capital: Evidence from the cities. Journal of Urban Economics, 34: 380-400.

Ruggles, Steven J., Trent Alexander, Katie Genadek, Ronald Goeken, Matthew B. Schroeder, and Matthew Sobek 2010. Integrated Public Use Microdata Series: Version 5.0 [Machine-readable database]. Minneapolis: University of Minnesota.

Scott, Allen J. 2010. Jobs or amenities? Destination choices of migrant engineers in the USA. Papers in Regional Science, 89(1): 43-63. 
Shapiro, Jesse M. 2006. Smart cities: Quality of life, productivity, and the growth effects of human capital. Review of Economics and Statistics, 88: 324-335.

Simon, Curtis J. 1998. Human capital and metropolitan employment growth. Journal of Urban Economics, 43: 223-243.

Simon, Curtis J. and Clark Nardinelli. 2002. Human capital and the rise of American cities, 1900-1990. Regional Science and Urban Economics, 32: 59-96.

Sjoquist, David L., and John V. Winters 2014. Merit aid and post-college retention in the state. Journal of Urban Economics, 80: 39-50.

Sjoquist, David L. and John V. Winters. 2015. State merit-based financial aid programs and college attainment. Journal of Regional Science, Forthcoming.

Stock, James, Jonathan Wright, and Motohiro Yogo. 2002. A survey of weak instruments and weak identification in generalized method of moments. Journal of Business \& Economic Statistics, 20(4): 518-29.

Trostel, Philip A. 2010. The impact of new college graduates on intrastate labor markets. Journal of Education Finance, 36(2): 186-213.

Venhorst, Viktor A. 2013. Graduate migration and regional familiarity. Tijdschrift Voor Economische en Sociale Geografie, 104(1), 109-119.

Waldorf. Brigitte S. 2009. Is human capital accumulation a self-propelling process? Comparing educational attainment levels of movers and stayers. Annals of Regional Science, 43: 323344.

Whisler, Ronald L., Brigitte S. Waldorf, Gordon F. Mulligan, and David A. Plane. 2008. Quality of life and the migration of the college-educated: A life-course approach. Growth and Change, 39: 58-94. 
Winters, John V. 2011a. Human capital, higher education institutions, and quality of life. Regional Science and Urban Economics, 41(5): 446-454.

Winters, John V., 2011b. Why are smart cities growing? Who moves and who stays. Journal of Regional Science, 51(2): 253-270.

Winters, John V. 2013. Human capital externalities and employment differences across metropolitan areas of the USA. Journal of Economic Geography, 13(5): 799-822.

Winters, John V. 2015. Estimating the returns to schooling using cohort-level maternal education as an instrument. Economics Letters, 126: 25-27.

Zheng, Liang. 2015. What city amenities matter in attracting smart people? Papers in Regional Science, Forthcoming. 
Table 1: College Shares by State of Birth and State of Residence, 2012 ACS

\begin{tabular}{|c|c|c|c|c|}
\hline \multirow{2}{*}{$\begin{array}{l}\text { State } \\
\text { Name }\end{array}$} & \multicolumn{2}{|c|}{ State of Birth } & \multicolumn{2}{|c|}{ State of Residence } \\
\hline & Rank & College Share & Rank & College Share \\
\hline Alabama & 47 & 24.7 & 43 & 24.9 \\
\hline Alaska & 37 & 25.9 & 27 & 28.7 \\
\hline Arizona & 42 & 25.2 & 35 & 27.3 \\
\hline Arkansas & 43 & 25.2 & 47 & 22.3 \\
\hline California & 29 & 29.7 & 17 & 31.5 \\
\hline Colorado & 14 & 33.9 & 5 & 38.5 \\
\hline Connecticut & 1 & 41.0 & 2 & 39.7 \\
\hline Delaware & 17 & 33.1 & 16 & 31.6 \\
\hline Florida & 34 & 26.9 & 34 & 27.4 \\
\hline Georgia & 44 & 25.1 & 23 & 29.8 \\
\hline Hawaii & 16 & 33.1 & 18 & 31.4 \\
\hline Idaho & 28 & 29.7 & 39 & 25.9 \\
\hline Illinois & 12 & 34.3 & 11 & 34.2 \\
\hline Indiana & 32 & 28.3 & 42 & 25.0 \\
\hline Iowa & 9 & 34.9 & 24 & 29.6 \\
\hline Kansas & 15 & 33.5 & 15 & 32.0 \\
\hline Kentucky & 48 & 24.5 & 45 & 23.5 \\
\hline Louisiana & 45 & 25.0 & 46 & 23.0 \\
\hline Maine & 36 & 26.6 & 30 & 28.3 \\
\hline Maryland & 19 & 32.4 & 4 & 38.8 \\
\hline Massachusetts & 2 & 40.8 & 1 & 42.9 \\
\hline Michigan & 25 & 30.1 & 31 & 28.0 \\
\hline Minnesota & 8 & 35.6 & 10 & 35.4 \\
\hline Mississippi & 49 & 24.3 & 49 & 21.1 \\
\hline Missouri & 24 & 30.3 & 29 & 28.3 \\
\hline Montana & 20 & 32.3 & 28 & 28.4 \\
\hline Nebraska & 5 & 36.4 & 13 & 32.7 \\
\hline Nevada & 39 & 25.5 & 48 & 22.1 \\
\hline New Hampshire & 10 & 34.4 & 7 & 36.7 \\
\hline New Jersey & 4 & 39.0 & 3 & 39.3 \\
\hline New Mexico & 41 & 25.3 & 40 & 25.4 \\
\hline New York & 3 & 39.2 & 8 & 36.2 \\
\hline North Carolina & 38 & 25.5 & 26 & 29.0 \\
\hline North Dakota & 7 & 36.0 & 20 & 31.1 \\
\hline Ohio & 27 & 29.8 & 36 & 27.3 \\
\hline Oklahoma & 31 & 28.7 & 44 & 24.1 \\
\hline Oregon & 33 & 27.8 & 22 & 30.6 \\
\hline Pennsylvania & 13 & 34.1 & 19 & 31.4 \\
\hline Rhode Island & 6 & 36.0 & 12 & 33.0 \\
\hline South Carolina & 46 & 24.9 & 37 & 26.3 \\
\hline South Dakota & 18 & 32.7 & 32 & 27.8 \\
\hline Tennessee & 40 & 25.4 & 38 & 26.3 \\
\hline Texas & 35 & 26.8 & 33 & 27.5 \\
\hline Utah & 21 & 32.0 & 21 & 30.7 \\
\hline Vermont & 22 & 30.8 & 9 & 36.2 \\
\hline Virginia & 30 & 29.6 & 6 & 37.9 \\
\hline Washington & 23 & 30.5 & 14 & 32.1 \\
\hline West Virginia & 50 & 23.6 & 50 & 20.0 \\
\hline Wisconsin & 11 & 34.4 & 25 & 29.4 \\
\hline Wyoming & 26 & 29.9 & 41 & 25.1 \\
\hline
\end{tabular}

Notes: the college shares report the percentage of persons ages 25-59 who have at least a bachelor's degree. 
Table 2: Cross-Sectional OLS Effects of Graduate Production on the Stock of College Graduates

\begin{tabular}{lcccccccc}
\hline Year & 1960 & 1970 & 1980 & 1990 & 2000 & 2006 & 2012 \\
\hline Ages 25-59 & 0.493 & 0.529 & 0.559 & 0.641 & 0.680 & 0.761 & 0.847 \\
& $(0.042)^{* * *}$ & $(0.058)^{* * *}$ & $(0.072)^{* * *}$ & $(0.089)^{* * *}$ & $(0.100)^{* * *}$ & $(0.088)^{* * *}$ & $(0.083)^{* * *}$ \\
Ages 25-29 & 0.587 & 0.573 & 0.598 & 0.809 & 0.883 & 0.871 & 0.965 \\
& $(0.050)^{* * *}$ & $(0.057)^{* * *}$ & $(0.061)^{* * *}$ & $(0.092)^{* * *}$ & $(0.072)^{* * *}$ & $(0.073)^{* * *}$ & $(0.086)^{* * *}$ \\
Ages 30-34 & 0.545 & 0.549 & 0.567 & 0.780 & 0.813 & 0.926 & 0.989 \\
& $(0.046)^{* * *}$ & $(0.063)^{* * *}$ & $(0.070)^{* * *}$ & $(0.087)^{* * *}$ & $(0.087)^{* * *}$ & $(0.069)^{* * *}$ & $(0.082)^{* * *}$ \\
Ages 35-39 & 0.485 & 0.562 & 0.593 & 0.609 & 0.722 & 0.818 & 0.816 \\
& $(0.050)^{* * *}$ & $(0.062)^{* * *}$ & $(0.086)^{* * *}$ & $(0.094)^{* * *}$ & $(0.112)^{* * *}$ & $(0.092)^{* * *}$ & $(0.078)^{* * *}$ \\
Ages 40-44 & 0.510 & 0.495 & 0.597 & 0.564 & 0.652 & 0.753 & 0.755 \\
& $(0.047)^{* * *}$ & $(0.063)^{* * *}$ & $(0.082)^{* * *}$ & $(0.096)^{* * *}$ & $(0.129)^{* * *}$ & $(0.107)^{* * *}$ & $(0.112)^{* * *}$ \\
Ages 45-49 & 0.471 & 0.478 & 0.553 & 0.593 & 0.569 & 0.705 & 0.690 \\
& $(0.060)^{* * *}$ & $(0.065)^{* * *}$ & $(0.078)^{* * *}$ & $(0.093)^{* * *}$ & $(0.113)^{* * *}$ & $(0.133)^{* * *}$ & $(0.117)^{* * *}$ \\
Ages 50-54 & 0.483 & 0.506 & 0.524 & 0.545 & 0.546 & 0.595 & 0.710 \\
& $(0.049)^{* * *}$ & $(0.067)^{* * *}$ & $(0.070)^{* * *}$ & $(0.086) * * *$ & $(0.098)^{* * *}$ & $(0.114)^{* * *}$ & $(0.120)^{* * *}$ \\
Ages 55-59 & 0.342 & 0.434 & 0.485 & 0.559 & 0.564 & 0.554 & 0.606 \\
& $(0.064)^{* * *}$ & $(0.061)^{* * *}$ & $(0.082)^{* * *}$ & $(0.086)^{* * *}$ & $(0.098)^{* * *}$ & $(0.091)^{* * *}$ & $(0.125)^{* * *}$ \\
\hline
\end{tabular}

Notes: Each 2x1 cell reports results for a separate OLS regression with 50 observations, one for each state. The dependent variable is the state of residence college share for the particular age group, and the explanatory variable is the state of birth college share for the same age group. The college share for each refers to the percentage of persons who have earned at least a bachelor's degree. Standard errors in parentheses are heteroskedasticity-robust. $* * *$ Statistically significantly different from zero at the $1 \%$ level of significance. 
Table 3: OLS Results Explaining the Stock of College Graduates For Cohorts Born 1963-1987

\begin{tabular}{lcccc}
\hline & $(1)$ & $(2)$ & $(3)$ & $(4)$ \\
\hline Birth State College Share & 0.827 & 0.815 & 0.521 & 0.477 \\
& $(0.051)^{* * *}$ & $(0.059)^{* * *}$ & $(0.030)^{* * *}$ & $(0.025)^{* * *}$ \\
Age Dummies & No & Yes & Yes & Yes \\
Year Dummies & No & Yes & Yes & Yes \\
Year of Birth Dummies & No & Yes & Yes & Yes \\
State Dummies & No & No & Yes & Yes \\
Cohort Sex \& Race/Ethnicity & No & No & No & Yes \\
Other Cohort Controls & No & No & No & Yes \\
Number of Age-Year-State Cohorts & 7700 & 7700 & 7700 & 7700 \\
\hline
\end{tabular}

Notes: The dependent variable is the state of residence college share by age and survey year. The college share, sex, and race/ethnicity explanatory variables are measured by birth state, age, and survey year. Other cohort controls include the unemployment rate, college-high school log wage gap, log cohort size, log median household income, and a state merit-aid program dummy measured based on state of birth at age 18. Standard errors are clustered by state.

***Statistically significantly different from zero at the $1 \%$ level of significance. 
Table 4: 2SLS Results Explaining the Stock of College Graduates Using the Maternal Education Instrument

\begin{tabular}{lcccc}
\hline & $(1)$ & $(2)$ & $(3)$ & $(4)$ \\
\hline First-Stage Results & & & & \\
\hline Mom with Bachelor's or Higher & 0.645 & 1.651 & 0.643 & 0.407 \\
& $(0.084)^{* * *}$ & $(0.195)^{* * *}$ & $(0.081)^{* * *}$ & $(0.043)^{* * * *}$ \\
Excluded Instrument F-Statistic & & & & \\
& 58.77 & 71.42 & 63.48 & 90.90 \\
2SLS Results & & & & \\
Birth State College Share & 1.033 & 1.107 & 0.870 & 0.522 \\
& $(0.084)^{* * *}$ & $(0.085)^{* * *}$ & $(0.204)^{* * *}$ & $(0.221)^{* *}$ \\
& & & & \\
Age Dummies & No & Yes & Yes & Yes \\
Year Dummies & No & Yes & Yes & Yes \\
Year of Birth Dummies & No & Yes & Yes & Yes \\
State Dummies & No & No & Yes & Yes \\
Cohort Sex \& Race/Ethnicity & No & No & No & Yes \\
Other Cohort Controls & No & No & No & Yes \\
Number of Age-Year-State Cohorts & 7700 & 7700 & 7700 & 7700 \\
\hline Not The & & & \\
\hline
\end{tabular}

Notes: The dependent variable is the state of residence college share by age and survey year. The college share, sex, and race/ethnicity explanatory variables are measured by birth state, age, and survey year. Other cohort controls include the unemployment rate, college-high school log wage gap, log cohort size, log median household income, and a state merit-aid program dummy measured based on state of birth at age 18. Standard errors are clustered by state.

**Statistically significantly different from zero at the 5\% level of significance; ***Significant at the $1 \%$ level. 
Table 5: Separate 2SLS Results for Ages 25-35 and 36-49 Using the Maternal Education Instrument

Ages 25-35 Ages 36-49

First-Stage Results

$\%$ Mom with Bachelor's or Higher

$0.296 \quad 0.325$

$(0.056) * * *$

$(0.081)^{* * *}$

Excluded Instrument F-Statistic

27.88

16.15

2SLS Results

Birth State College Share

$0.750 \quad 0.366$

$(0.258)^{* * *} \quad(0.165)^{* *}$

Age Dummies

Yes $\quad$ Yes

Year Dummies

Yes Yes

Year of Birth Dummies

Yes Yes

State Dummies

Yes Yes

Cohort Sex \& Race/Ethnicity

Yes Yes

Other Cohort Controls

Yes Yes

Number of Age-Year-State Cohorts

3850

3850

Notes: The dependent variable is the state of residence college share by age and survey year. The college share, sex, and race/ethnicity explanatory variables are measured by birth state, age, and survey year. Other cohort controls include the unemployment rate, college-high school log wage gap, log cohort size, log median household income, and a state merit-aid program dummy measured based on state of birth at age 18 . Standard errors are clustered by state.

**Statistically significantly different from zero at the $5 \%$ level of significance; *** Significant at the $1 \%$ level. 


\section{Appendix}

Table A: 2SLS Results Using One-Year Lagged College Share in Birth State as an Instrument

\begin{tabular}{lcccc}
\hline & $(1)$ & $(2)$ & $(3)$ & $(4)$ \\
\hline First-Stage Results & & & & \\
Birth State College Share in t-1 & 0.839 & 0.834 & 0.166 & 0.087 \\
& $(0.026)^{* * *}$ & $(0.030)^{* * *}$ & $(0.035)^{* * * *}$ & $(0.016)^{* * * *}$ \\
Excluded Instrument F-Statistic & & & & \\
& 1024.75 & 756.58 & 22.22 & 29.59 \\
2SLS Results & & & & \\
Birth State College Share & & & & \\
& 0.893 & 0.884 & 0.860 & 0.638 \\
& $(0.056)^{* * *}$ & $(0.065)^{* * *}$ & $(0.134)^{* * * *}$ & $(0.211)^{* * *}$ \\
Age Dummies & & & & \\
Year Dummies & No & Yes & Yes & Yes \\
Year of Birth Dummies & No & Yes & Yes & Yes \\
State Dummies & No & Yes & Yes & Yes \\
Cohort Sex \& Race/Ethnicity & No & No & Yes & Yes \\
Other Cohort Controls & No & No & No & Yes \\
Number of Age-Year-State Cohorts & No & No & No & Yes \\
\hline Nots: The & 6750 & 6750 & 6750 & 6750 \\
\hline
\end{tabular}

Notes: The dependent variable is the state of residence college share by age and survey year. The college share, sex, and race/ethnicity explanatory variables are measured by birth state, age, and survey year. Other cohort controls include the unemployment rate, college-high school log wage gap, log cohort size, log median household income, and a state merit-aid program dummy measured based on state of birth at age 18. Standard errors are clustered by state.

***Statistically significantly different from zero at the $1 \%$ level of significance. 
Table B: 2SLS Results Explaining the Stock of College Graduates Using Both Instruments

\begin{tabular}{lcccc}
\hline & $(1)$ & $(2)$ & $(3)$ & $(4)$ \\
\hline First-Stage Results & & & & \\
Birth State College Share in t-1 & 0.780 & 0.685 & 0.091 & 0.060 \\
& $(0.026)^{* * *}$ & $(0.034)^{* * *}$ & $(0.015)^{* * *}$ & $(0.014)^{* * *}$ \\
\% Mom with Bachelor's or Higher & 0.213 & 0.510 & 0.569 & 0.376 \\
& $(0.015)^{* * *}$ & $(0.080)^{* * *}$ & $(0.072)^{* * *}$ & $(0.041)^{* * *}$ \\
& & & \\
Excluded Instrument F-Statistic & 1185.80 & 544.40 & 42.85 & 46.07 \\
& & & \\
2SLS Results & & & \\
Birth State College Share & 0.906 & 0.930 & 0.873 & 0.557 \\
& $(0.055)^{* * *}$ & $(0.063)^{* * *}$ & $(0.190)^{* * *}$ & $(0.220)^{* *}$ \\
& & & \\
Hansen J-Statistic p-value & 0.108 & 0.001 & 0.925 & 0.608 \\
& & & & \\
Age Dummies & No & Yes & Yes & Yes \\
Year Dummies & No & Yes & Yes & Yes \\
Year of Birth Dummies & No & Yes & Yes & Yes \\
State Dummies & No & No & Yes & Yes \\
Cohort Sex \& Race/Ethnicity & No & No & No & Yes \\
Other Cohort Controls & No & No & No & Yes \\
Number of Age-Year-State Cohorts & 6750 & 6750 & 6750 & 6750 \\
\hline
\end{tabular}

Notes: The dependent variable is the state of residence college share by age and survey year. The college share, sex, and race/ethnicity explanatory variables are measured by birth state, age, and survey year. Other cohort controls include the unemployment rate, college-high school log wage gap, log cohort size, log median household income, and a state merit-aid program dummy measured based on state of birth at age 18. Standard errors are clustered by state.

**Statistically significantly different from zero at the $5 \%$ level of significance; ***Statistically significantly different from zero at the $1 \%$ level of significance. 
Table C: Separate 2SLS Results for Ages 25-35 and 36-49 Using One-Year Instrument and Both Instruments

(1)

(2)

(3)

Ages 25-35

Ages 25-35

Ages 36-49

Ages 36-49

First-Stage Results

Birth State College Share in t-1

0.065

0.053

0.027

0.018

$(0.020)^{* * *}$

$(0.019)^{* * *}$

(0.019)

(0.018)

$\%$ Mom with Bachelor's or Higher

0.239

0.315

$(0.060) * * *$

$(0.076) * * *$

Excluded Instrument F-Statistic

10.34

11.73

2.15

9.14

2SLS Results

Birth State College Share

$\begin{array}{cccc}1.066 & 0.887 & 1.458 & 0.361 \\ (0.357)^{* * *} & (0.270)^{* * *} & (0.767)^{*} & (0.179)^{* *}\end{array}$

Hansen Overidentification p-value

0.385

0.037

Age Dummies

Year Dummies

Yes

Yes

Yes

Yes

Year of Birth Dummies

Yes

Yes

Yes

Yes

State Dummies

Yes

Yes

Yes

Yes

Cohort Sex \& Race/Ethnicity

Yes

Yes

Yes

Yes

Yes

Yes

Yes

Yes

Other Cohort Controls

Yes

Yes

Yes

Yes

Number of Age-Year-State Cohorts

3300

3300

3450

3450

Notes: The dependent variable is the state of residence college share by age and survey year. The college share, sex, and race/ethnicity explanatory variables are measured by birth state, age, and survey year. Other cohort controls include the unemployment rate, college-high school log wage gap, log cohort size, log median household income, and a state merit-aid program dummy measured based on state of birth at age 18. Standard errors are clustered by state.

**Statistically significantly different from zero at the 5\% level of significance; ***Statistically significantly different from zero at the $1 \%$ level of significance. 